\title{
Determinants of Tax Efficiency Perceptions by Domestic Taxpayers in Kenya: The Case of Nairobi
}

\author{
Ndemo Alfonce Mosomi \\ School of Business and Management, KCA University, Nairobi, Kenya \\ Email address: \\ alndemo@gmail.com
}

\section{To cite this article:}

Ndemo Alfonce Mosomi. Determinants of Tax Efficiency Perceptions by Domestic Taxpayers in Kenya: The Case of Nairobi. International Journal of Economics, Finance and Management Sciences. Vol. 3, No. 5, 2015, pp. 541-545. doi: 10.11648/j.ijefm.20150305.25

\begin{abstract}
The study sought to investigate the determinants of tax efficiency perceptions by domestic taxpayers in Kenya with emphasis on Nairobi. To increase the amount of revenue, the government has in the recent past introduced excise duty on mobile money transfer, seen VAT bill passed and operationalized with campaigns to encourage Kenyans to pay taxes. The big issue in the study was that Kenya's tax system was characterized by low efficiency, high collection charges, waste of time for taxpayers and the staff, low amounts of taxes raised and deviation of optimum allocation of resources. The specific objectives for the study were to determine the effect of given factors on tax efficiency such as the digitization of tax records to ensure transparency and credibility of records; implementing integrated tax collection system to credibly consolidate revenues by various Kenya Revenue Authority agencies to ensure proper accounting for taxes raised by the agencies; organizational restructuring by increasing the number of offices and agents of tax collection to make it easy to collect taxes and embracing electronic payment methods to make it easy for taxpayers to make payments. To meet the research objectives, a descriptive research design was used to gather information on the understanding of tax, challenges encountered in paying and collecting taxes and ways of enhancing efficiency. A linear regression model was used together with SPSS software for data analysis giving t-statistic values of 4.527, 3.346, 8.159 and 8.086 for digitization, organization restructuring, electronic methods and integrated system respectively all of which were greater than two meaning that the variables were statistically significant in explaining tax efficiency. The coefficients for digitization, organization restructuring, electronic methods and integrated system were $0.297,0.204,0.348$ and 0.302 respectively. All of them being positive meant that there was positive relationship between each independent variable and the dependent variable, tax efficiency. The study recommended that Kenya Revenue Authority should educate taxpayers on matters to do with Kenyan tax system; seek to raise more revenue from the informal sector; increase the number of tax collecting offices and agents in some specific areas that have income generating activities; simplify the electronic payment methods and implement an integrated tax system.
\end{abstract}

Keywords: Domestic Taxes, Integrated Tax Collection System, Electronic Payment System, Digitization, Organization Restructuring, Tax Efficiency

\section{Introduction}

One of the most important policy upon which most economists agree is that emerging nations must increasingly mobilize their own internal resources to provide economic growth. The most important instrument by which resources are marshaled is through the implementation of an effective tax policy [1].

Taxation is the single largest source of government budgetary resources in Kenya. Between 1995 and 2004, tax revenue constituted 80.4 percent of total government revenue (including grants). Relatively, the importance of non-tax revenue is also significant in sustaining the public budget, although its importance is much less than the role of taxation given that it's share over the same period was 15.1 percent. Foreign grants play a minimal role as they averaged only 4.5 percent. Given its central role, taxation has been applied to meet two objectives. First, taxation is used to raise sufficient revenue to fund public spending without recourse to excessive public sector borrowing. Second, it is used to mobilize revenue in ways that are equitable and that minimize its disincentive effects on economic activities [2].

The main shortcoming of Kenya's tax structure since independence has been its over-dependence on a small number of sources of tax revenue, namely trade taxes, sales 
tax/value added tax and income tax [3-5]. The trade taxes, sales tax/value added tax on various imported products are vulnerable to external events because their prices are determined in the world market and tend to be volatile. This has resulted in inadequate tax revenues and continuous existence of budget deficits [6].

Kenya introduced the Tax Modernization Programme in 1986 with the hope that this would enhance revenue collection, improve tax administration and reduce compliance and collection costs. Despite the tax modernization, there are concerns that the challenges that confront the Treasury and Kenya Revenue Authority today are not much different from the challenges that faced these revenue authorities before the reforms. There are also concerns that tax competitiveness in Kenya is low and the country remains among the most tax unfriendly countries in the world [2].

The tax system in developing countries imposes high expenses on the society. Low efficiency, high collection charges, waste of time for taxpayers and the staff, and the low amounts of received taxes and the deviation of optimum allocation of resources are some of the features of such systems [7].

Treasury should focus on increasing tax efficiency and compliance, which is quite low in the country. For instance some supermarkets, shops, hardwares, stalls, chemists, transport companies, restaurants, among other numerous outlets of goods and services do not offer electronic tax register slips, but manually written receipts, thus evading tax. Kenya has sought to improve tax efficiency and compliance. There has been a major campaign to encourage tax payment especially by the immediate former president, Mr. Mwai Kibaki together with the Kenya Revenues Authority (KRA) officials. KRA have introduced the electronic tax register machines to assist providers of goods and services electronically capture their taxes. KRA have also facilitated online uploading of taxes by companies and individuals as well as facilitating online filing of returns. There is also the introduction of integrated system for Customs where the taxes paid at the collection point are automatically captured to the KRA system.

Several studies have been undertaken on the tax revenues [3-6, 8-12]. Such studies omitted some key determinants of tax efficiency, such as the digitization of tax records to ensure transparency and credibility of records; implementing integrated tax collection system to credibly consolidate revenues by various Kenya Revenue Authority departments and agencies to ensure proper accounting for taxes raised by the departments; organization restructuring by increasing the number of offices and agents of tax collection to make it easy to collect taxes and introducing electronic payment methods to make it easy for taxpayers to make payments. Due to the omission of some of the determinants of tax efficiency and compliance, the objectives of having an efficient tax system are not met resulting in inaccurate and unreliable estimated income, hence failing to meet the set targets.

\section{Research Objectives}

The main objective of the research was to establish the determinants of tax efficiency perceptions by domestic taxpayers in Kenya. The specific objectives of the study were:

i. To establish the effect of digitization of records on tax efficiency

ii. To establish the effect of an Integrated Tax Collection System on tax efficiency

iii. To establish the effect of organizational restructuring on tax efficiency

iv. To establish the effect of using electronic payment methods on tax efficiency.

\section{Concept of Tax Efficiency}

An efficient tax system is a system which collects the highest amount of taxes from the existing resources in the fastest possible time duration and with the lowest possible collection costs [13]. From this definition three facets of tax efficiency arise. The first one being on the revenue raised, with efficient systems raising high revenues. The second facet is on the time spent on paying or collecting revenue. Efficient systems ensure that taxes are paid and collected in the shortest time possible. The last facet of tax efficiency is on the cost of collecting tax. Efficient systems ensure that the cost of paying and collecting tax is minimized as much as possible. This is in line with the Canon of Economy in Taxation. Therefore tax efficiency involves maximizing tax revenue while at the same time minimizing the cost and time of raising the tax revenue.

\section{Literature Review}

Various researchers have used income-elasticity and buoyancy to measure performance of various tax reforms and efficiency. These studies have covered different countries with varying degree of results.

Income-elasticity and buoyancy in Central America were estimated measuring the impact of GDP on tax revenue and it was found that income elasticity of the tax revenue was less than unity. This implied that the tax structure was stable and therefore tax revenue growth was not at a rate proportional to growth in income [14].

Having had some reforms aimed at raising revenue generation, a study was carried out to examine the revenue productivity implications of these tax reforms in Tanzania. The overall elasticity was 0.76 with buoyancy of 1.06 implying that the tax reforms in Tanzania did not meet the objective of raising tax revenues [9].

In the evaluation of the productivity of the Nigerian tax system, a wide variation in the level of tax revenue by tax source was identified. The study concluded that tax information should be improved for ease of performance evaluation and facilitation of macro-economic planning and implementation [11]. 
Ghana having carried out some reforms aimed at increasing tax revenue productivity, a study on pre-reform and post-reform tax revenue productivity was carried out. A pre-reform buoyancy of 0.72 and elasticity of 0.71 was recorded and an increased post-reform buoyancy of 1.29 and elasticity of 1.22. This implied that the reforms played a significant role in increasing tax revenue productivity [15].

As in the case of Ghana, a study was carried out to show that tax reforms in Zambia had improved the country's revenue productivity. Elasticity of 1.15 and buoyancy of 2.0 were recorded [16].

A study on the revenue productivity of tax reforms in Kenya was carried out. The results showed an income elasticity of total tax structure of 0.67 and buoyancy of 1.19 for the period 1972 to 1981 implying a buoyant tax system and decrease in tax revenue as a fraction of GDP. The results further showed an income elasticity of total tax structure of 0.86 and buoyancy of 1 for the period 1982 to 1991 . The study's conclusion was that the system did not meet its target in terms of revenue [17].

Another study was carried out to determine whether the reforms made yielded individual taxes responsive to changes in national income. There was an indication that reform positively affected the overall tax structure and on individual tax handles. The study concluded that despite the positive impact, the reforms failed to make VAT responsive to changes in income [3]. A regression of tax revenue on income was performed concluding that slowdown in economic growth had resulted in high levels of taxation that did not match delivery of public goods and services [4].

An analysis of responsiveness of tax revenue to changes in national income in Kenya between 1986 and 2009 was carried out. The results suggested that the overall tax system had a buoyancy of 0.525 , meaning that the tax system yielded a $0.525 \%$ change in tax revenue, as a result of both automatic changes and discretionary policy for every $1 \%$ change in GDP. Thus a decreasing proportion of incremental income was transferred to the government in the form of taxes, implying that the tax system was less buoyant [12].

With Kenya aligning its development agenda towards Vision 2030, a study was carried out to estimate the effect of tax reforms on buoyancy of income tax and value added tax, as well as estimating the effect of the reforms on elasticity of the tax system. The study was guided by the Tax Modernization Programme of 1986 and the Kenya Vision 2030. The study showed that the reforms had a positive impact on productivity of income tax, but did not have a positive impact on productivity of value added tax. The positive impact of reforms on the productivity of income tax was as a result of the relative effectiveness of income tax reform that made the tax system simpler and reduced avenues for evasion and corruption, whereas the low elasticity of value added tax might have been caused by tax evasion and collusion between the tax collectors and tax payers. In spite of the good performance of income tax as a result of reforms, further reform needs to be done particularly on the inelastic value added tax. These reforms include: reduction of rates and exemptions, increasing the number of tax collectors, imposing tougher penalties for those found guilty of evasion, strengthening audit skills, taxation of absentee landlords and income from rental houses [18].

World Bank carried out a study on the efficiency of paying tax in Kenya and found that taxpayers face significant compliance costs and this interferes with their willingness to pay. Thus, it is evident that low compliance is mainly an administrative issue related to Kenya Revenue Authority, and their costly administrative structure itself contributes to the problem. For instance, a taxpayer in Kenya can be audited three times (for value added tax, income tax, excise tax) but yet still be dealing with Kenya Revenue Authority only. Furthermore, if liable to a levy, the taxpayer may also be audited by government ministries. The tax-by-tax organization of Kenya Revenue Authority needs to be revisited. Best international practices suggest that revenue administration be organized according to function, so that audits are conducted as a single operation, and not by the type of tax. For example, one auditing section should undertake tax audit in a firm for income tax, value added tax, excise tax and any other taxes collected by the government [19].

In evaluating performance of Kenya Revenue Authority, the Kenyan National Treasury Ministry found out that there are other problems such as the failure to utilize the personal identification number (PIN) assigned to each taxpayer. It certainly does not help the taxpayer to have so many numbers and codes, even though taxes and other payments are made to the same government agency. This could be associated to the lack of proper systems. Having a good system would enable Kenya Revenue Authority to interact with taxpayers through an integrated computer interface, saving not only time but also increasing compliance, as the PIN facilitates follow-up. With these systems, it would also become easier to consolidate payment of all taxes and levies [20].

In all the above studies, there was a general agreement that there is need to improve tax collection, administration, efficiency and productivity of taxation, while lowering the rates, and gain tax effectiveness through greater tax elasticity. However there were no highlights on how this can be effectively achieved. The emphasis had been on the investigation of the impact of reforms on the tax productivity. Some of the researchers identified the years reforms were implemented but not the specific details of the reforms. Other researchers identified the specific reforms and discussed just a few components such as creation of Kenya Revenue Authority and introduction of value added tax leaving out many more factors that can improve tax efficiency. Yet other researchers concentrated on use of income-elasticity and buoyancy to measure performance of various reforms on efficiency. There was no detailed explanation on the reforms that were carried out to result on the performance being measured. This resulted to a knowledge gap in matters of tax efficiency especially in Kenya, hence need for further research on tax efficiency with emphasis on specific factors. 


\section{Study Model}

The study employed the generic regression model below to test the dependence of tax efficiency on the four independent variables:

$$
\mathrm{T}=\beta_{0}+\beta_{1} \mathrm{D}+\beta_{2} \mathrm{I}+\beta_{3} \mathrm{E}+\beta_{4} \mathrm{~N}+\mathrm{u}
$$

Where: $\mathrm{T}=$ Tax Efficiency

$\beta_{0}=\mathrm{A}$ constant, the value of $\mathrm{T}$ when all the independent variables are zero

$\mathrm{D}=$ Digitization of records

I = Integratedtax collection system

$\mathrm{E}=$ Use of electronic payment methods

$\mathrm{N}=$ Organizational restructuring

$\mathrm{u}=$ Error term, normally distributed about a mean of 0

\section{Results and Discussion}

Regression Results

Table 1. Model Summary.

\begin{tabular}{llllll}
\hline Model & R & R Square & $\begin{array}{l}\text { Adjusted R } \\
\text { Square }\end{array}$ & $\begin{array}{l}\text { Std. Error of } \\
\text { the Estimate }\end{array}$ & $\begin{array}{l}\text { Durbin- } \\
\text { Watson }\end{array}$ \\
\hline 1 & $.914^{\mathrm{a}}$ & .836 & .833 & .42903 & 2.184 \\
\hline
\end{tabular}

Source: Research Data, 2015

From Table 1 above, the R Square was 0.836 while the Adjusted R Square was 0.833. This meant that the four independent variables for the study were important in explaining the variations in tax efficiency. The DurbinWatson was 2.184 which was close to two meaning that there was no problem of autocorrelation.

Table 2. Regression Coefficients.

\begin{tabular}{lll}
\hline Variable & B & t \\
\hline $\begin{array}{l}\text { Effect of digitization on tax efficiency } \\
\text { Effect of organizational restructuring on tax } \\
\text { efficiency }\end{array}$ & .297 & 4.527 \\
$\begin{array}{l}\text { Effect of using electronic method to pay tax on tax } \\
\text { efficiency }\end{array}$ & .348 & 8.346 \\
\begin{tabular}{l} 
Effect of integrated tax system on tax efficiency \\
\hline
\end{tabular} & .302 & 8.086 \\
\hline
\end{tabular}

Source: Research Data, 2015

From Table 2 above, the coefficients for digitization, organization restructuring, electronic methods and integrated system were $0.297,0.204,0.348$ and 0.302 respectively. All of them being positive meant that there was positive relationship between each independent variable and the dependent variable. Each predictor variable positively affected the independent variable.

The significance of the independent variables was indicated by the t-statistic in testing the null hypotheses. From Table 2 above, the t-statistic for digitization was 4.527 which was more than two meaning that the null hypothesis was rejected. Therefore the variable was statistically significant in explaining tax efficiency. The t-statistic for organization restructuring was 3.346 which was more than two meaning that the null hypothesis was rejected. Therefore the variable was statistically significant in explaining tax efficiency. The t-statistic for electronic methods was 8.159 which was more than two meaning that the null hypothesis was rejected. Therefore the variable was statistically significant in explaining tax efficiency. The t-statistic for integrated system was 8.086 which was more than two meaning that the null hypothesis was rejected. Therefore the variable was statistically significant in explaining tax efficiency. This meant that the organization restructuring, digitization, electronic methods and integrated system significantly affected tax efficiency.

\section{Conclusions}

It was established that digitization had a positive effect on tax efficiency. It ensures that there is proper keeping and updating of taxpayers' records and further boosts transparency which improves tax efficiency. Organizational restructuring by increasing the number of offices and agents for collecting tax would make it easy and convenient for the taxpayers to pay tax thus encouraging them to pay tax. Electronic methods of paying tax would improve convenience of paying tax and thus promote tax efficiency. An integrated tax system would streamline tax collection by bringing all taxes and taxpayers in one platform thus making it easy to monitor revenue generation in a more transparent manner leading to improved efficiency.

Recommendations include: Kenya Revenue Authority to educate the taxpayers on matters to do with Kenyan tax system; seek to raise more revenue from the informal sector; increase the number of tax collecting offices and agents in some specific areas that have income generating activities; simplify the electronic payment methods and implement an integrated tax system.

The suggested study areas for further research include: The challenges of paying taxes using the electronic methods; the viability of increasing the number of Kenya Revenue Authority offices and agents in remote areas; ways of motivating taxpayers to pay taxes; ways of enabling the Kenyan taxpayers understand the Kenyan tax system; and ways of increasing tax collected from the informal sector.

\section{Acknowledgments}

I would like to first thank the Almighty God for the gift of life, ability and opportunity to carry out research and come up with this article. I also wish to appreciate the continued support of my family, especially my wife Veronica, in every step I take in life. I am indebted to my employer National Bank of Kenya for financial assistance accorded to me towards realizing my academic goals and professional growth. I appreciate all the assistance I got from my colleagues and Kenya Revenue Authority officials in collecting data. 


\section{References}

[1] Wilford, S.D., and Wilford, W.T. (1978), "Revenue performance and revenue-income stability in the Third World," Economic Development and Cultural Change, 26, pp.505 - 523.

[2] Moyi, E., and Ronge, R. (2006), "Taxation and tax modernization in Kenya: A diagnosis of performance and options for further reforms," Nairobi: Institute of Economic Affairs.

[3] Muriithi, M., and Moyi, D. (2003), "Tax reforms and revenue mobilization in Kenya," African Economic Research Consortium Research Paper No 131, pp.130-134.

[4] Wawire, N. W. (2003), "Trends in Kenya's tax ratios and tax effort indices and their implication for future tax reforms," In Illiera E.V. (Ed). Egarton Journal 4, pp.256-279.

[5] Wawire, N. W. (2006), "Determinants of tax revenues in Kenya," Unpublished Ph.D. thesis. Nairobi: Kenyatta University.

[6] Wawire, N. W. (2011, March), "Determinants of value added tax revenue in Kenya," In proceedings of the $11^{\text {th }}$ Tax Mobilization Conference, Nairobi, Kenya.

[7] Farzbod, J. (2000), "Investigation of the effective factors in the tax efficiency," Unpublished M.A. thesis. Tehran: Governmental Management Training Center.

[8] Ole, A. M. (1975), "Income elasticity of tax structure in Kenya: 1962/63-1972/73," Unpublished M.A research Paper. Nairobi: University of Nairobi.

[9] Osoro, N. E. (1993), "Revenue productivity: Implications of tax reforms in Tanzania," Africa Economic Research Consortium Research Paper no. 20, pp.71-75.

[10] Osoro, N. E. (1995), "Tax reforms in Tanzania: Motivations, directions and implications," Africa Economic Research Consortium Research Paper no. 38, pp.53-59.

[11] Ariyo, A. (1997), "Productivity of the Nigerian tax system: 1970 - 1990," African Economic Research Consortium Research Paper no. 67, pp.57-58.

[12] Okech, T., and Mburu, P. (2011), “Analysis of responsiveness of tax revenue to changes in national income in Kenya between 1986 -2009," International Journal of Business and Social Science Vol. 2 No. 21 [Special Issue - November 2011].

[13] Shahroodi, S. M. (2010), "Investigation of the effective factors in the efficiency of tax system," Unpublished M.A. Thesis. Tehran: Shahroud Industrial University, Faculty of Industrial Engineering and Management.

[14] Wilford, S.D. and Wilford, W.T. (1978), "Estimates of revenue elasticity and buoyancy in Central America: 1955- 1974," In Toye, J.F.J (Ed.), Taxation and Economic Development. London: Frank Cass \& Co. Ltd. Pp. 83 - 100.

[15] Kusi, N. K. (1998), "Tax reforms and revenue productivity in Ghana," African Economic Research Consortium Research Paper no. 74, pp.62-67.

[16] Milambo, M. (2001), "Elasticity and buoyancy of the Zambia tax system," Unpublished M.A. Research Paper. Nairobi: University of Nairobi.

[17] Njoroge, J. W. (1993), "Revenue productivity of tax reforms in Kenya 1972/73-1991/92," Unpublished M.A. Research Paper. Nairobi: University of Nairobi.

[18] Nyandieka, K. M. (2013), "Impact of tax reforms on revenue productivity in Kenya," Unpublished M.A. Research Paper. Nairobi: Kenyatta University.

[19] World Bank (2012), "Kenya: A policy agenda to restore growth," Washington D.C: The World Bank.

[20] Government of Kenya (GoK) (2013), "Economic recovery strategy for wealth and employment creation, 2013-2017," Nairobi: The National Treasury. 